\title{
Interrogating resilience: toward a typology to improve its operationalization
}

\author{
$\underline{\text { Julie L. Davidson }}{ }^{1}, \underline{\text { Chris Jacobson }}^{2}, \underline{\text { Anna Lyth }}^{1,2}, \underline{\text { Aysin Dedekorkut-Howes }}^{3}, \underline{\text { Claudia L. Baldwin }}^{2}, \underline{\text { Joanna C. Ellison }}^{1}, \underline{\text { Neil J. }}^{2}$

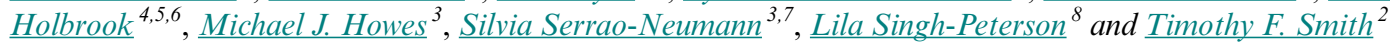

\begin{abstract}
In the context of accelerated global change, the concept of resilience, with its roots in ecological theory and complex adaptive systems, has emerged as the favored framework for understanding and responding to the dynamics of change. Its transfer from ecological to social contexts, however, has led to the concept being interpreted in multiple ways across numerous disciplines causing significant challenges for its practical application. The aim of this paper is to improve conceptual clarity within resilience thinking so that resilience can be interpreted and articulated in ways that enhance its utility and explanatory power, not only theoretically but also operationally. We argue that the current confusion and ambiguity within resilience thinking is problematic for operationalizing the concept within policy making. To achieve our aim, we interrogate resilience interpretations used within a number of academic and practice domains in the forefront of contending with the disruptive and sometimes catastrophic effects of global change (primarily due to climate change) on ecological and human-nature systems. We demonstrate evolution and convergence among disciplines in the interpretations and theoretical underpinnings of resilience and in engagement with cross-scale considerations. From our analysis, we identify core conceptual elements to be considered in policy responses if resilience is to fulfill its potential in improving decision making for change. We offer an original classification of resilience definitions in current use and a typology of resilience interpretations. We conclude that resilience thinking must be open to alternative traditions and interpretations if it is to become a theoretically and operationally powerful paradigm.
\end{abstract}

Key Words: climate change; complex adaptive systems; conceptual clarity; policy making; resilience; typology

\section{INTRODUCTION}

With an increased likelihood of major shifts in earth systems, greater emphasis is being placed on maintaining their resilience to disruptive change and even building the ability to steer humanenvironment systems away from unproductive or hazardous regimes toward more sustainable and less hazardous ones (Walker et al. 2004, Olsson et al. 2004, 2008, Adger et al. 2005, Folke 2006, Bohensky 2008, Folke et al. 2009). Thus the concept of resilience has entered the lexicons of various disciplines confronted with extraordinary change, not only in the natural sciences but increasingly in the social sciences (Cote and Nightingale 2012, Brown 2014). In moving from ecological to social contexts, however, resilience has lost some of its precision and become conceptually vague and fuzzy (Brand and Jax 2007) so that it is now characterized by "blurred boundaries of concepts, metaphors and an implicit mix of normative and positive aspects" (Strunz 2012:114). Fuzzy concepts are described as concepts that lack clear definition, are difficult to operationalize, and lack evidence (Markusen 1999), implying that profound losses of resilience are likely easier to recognize than are resilient systems (Boin et al. 2010).

Conversely, some scholars argue that blurred boundaries and conceptual fuzziness may be particularly appropriate to inter- and transdisciplinary contexts where research questions are unclear and creativity is required (Strunz 2012, Deppisch and Hasibovic 2013), while others maintain they may simply be a function of the concept's immaturity and detachment from policy (Lagendijk 2003, Chelleri 2012). Whatever the reasons, this ambiguity means that the concept is open to many interpretations across multiple theoretical and practice contexts (Stead 2013). Indeed, we argue that these attempts to apply the concept of resilience to so many different fields have impeded the continual improvement of its operationalization within policy making and implementation because of the following:

- There is a lack of consensus on the concept's meaning as a result of multiple definitions;

- Policy makers may use the same language but have differing interpretations;

- This confusion often prevents a common set of goals being generated;

- It is difficult to measure progress in improving or building resilience.

These issues are particularly relevant to complex "systems" problems that necessarily involve interactions between different domains where diverse resilience interpretations are used to inform theory and practice.

Our overall aim in this paper is to bring some clarity to the concept of resilience so that it can be interpreted and articulated in ways that enhance its utility and explanatory power. Facilitating common understandings and goals and improving ability to measure progress in developing resilience should provide the basis for the practical operationalization of the concept. Additionally, because we think resilience is still a useful concept, one of our objectives in interrogating the multiple resilience interpretations

\footnotetext{
${ }^{1}$ Discipline of Geography and Spatial Sciences, School of Land and Food, University of Tasmania, Tasmania, Australia, ${ }^{2}$ Sustainability Research Centre, University of the Sunshine Coast, Queensland, Australia, ${ }^{3}$ Griffith School of Environment \& Urban Research Program, Griffith University, Queensland, Australia, ${ }^{4}$ Institute for Marine and Antarctic Studies, University of Tasmania, Hobart, Tasmania, Australia, ${ }^{5}$ ARC Centre of Excellence for Climate System Science, Hobart, Tasmania, Australia, ${ }^{6}$ Centre for Marine Socioecology, University of Tasmania, Hobart, Tasmania, Australia, ${ }^{7}$ CRC for Water Sensitive Cities, Monash University, Victoria, Australia, ${ }^{8}$ Australian Centre for Pacific Island Research, University of the Sunshine Coast, Queensland, Australia
} 
is to prevent resilience becoming little more than a "rhetorical device with little influence on actual decision-making" (Benson and Craig 2014:780), as has happened to some extent to the concept of sustainability.

Our argument is that the difficulties of defining and operationalizing resilience have arisen because of how the term emerged. Indeed, the escalating adoption of resilience in multiple practice and policy domains increases the urgency to interrogate and better delimit the concept. This paper provides the evidence supporting these arguments through dissecting diverse resilience interpretations. It does so by tracing key foundational theoretical traditions, mapping trends in definitional content and attention to scale, and identifying the key conceptual elements encompassed within resilience definitions. Our analysis shows that some maturation and convergence of interpretations is occurring and that, although there are common conceptual elements across most of the domains, there are also significant differences. From this analysis, we develop two analytical frameworks, a classification of resilience definitions, and a typology of resilience interpretations. Through the typology, we illuminate the multiple differences in interpretation and clarify the conceptual elements central to delineating resilience types. An important insight from the typology is that different levels of system disturbance call for different resilience responses.

\section{METHODOLOGY}

As a framework for understanding system dynamics, the resilience concept has undergone some evolution since it was first proposed by Holling in 1973. To demonstrate these changes, we first needed to develop an understanding of progress in conceptual development. To this end, we selected five academic and practice areas that we call "domains" that are at the forefront of researching disruptions from global environmental change, and are recognized as developing traditions of resilience theorizing, namely, ecological (ER), social-ecological (SER), urban (UR), disaster (DR), and community (CR). Within these domains, the aim of climate change adaptation has generally been to increase socioeconomic and biophysical resilience. This makes them useful cases for investigating variations in conceptual composition and evolution. To further enhance the study, the author team applied their expertise from a wide range of relevant research areas, including ecology, climatology and oceanography, socialecological systems, disaster, urban and community development studies, sustainability, and environmental governance. Their expertise was applied to literature reviews of each domain and synthesis of these data sets.

Step 1 involved groups of two and three authors undertaking literature reviews for each domain to locate resilience definitions, conceptual traditions informing them, and evidence of attention to scale. With regard to scale, we focused on cross-scale interactions (CSI) because (i) these are crucial to system resilience (Peterson et al. 1998), and (ii) there are profound implications of ignoring this critical system attribute for resilience's practical implementation. Publications were selected for the period 2000 to 2014 from Scopus and the top 50 hits on Google Scholar using the search terms "resilience" and "[resilience domain]," for example, "resilience" and "ecology." Highly cited literature from the prior period and coauthors' personal libraries were also included in the reviews. The definitional data were used for two purposes: (1) to develop a classification of resilience definitions; and (2) to construct a typology of ideal resilience types, where "ideal" delineates a set of characteristics that are specific or unique to a given type (see Doty and Glick 1994 for further explanation).

For Step 2, different author groupings synthesized these data across the five domains. The data were analyzed to identify changes over time in definitional content, scale treatments, and underpinning theoretical traditions to confirm maturation and perhaps convergence of interpretations and understanding of resilience. This step also involved delineating conceptual elements from the definitions. From the definitions collected for each domain, subcategories were identified based on conceptual content. These formed the classification (Step 3), which was then used as the basis of the typology.

Our task in differentiating between domains was complicated by reliance of some domains on basic ER or SER definitions and by overlaps between some of the domains. Thus, convergence around crises and disasters among CR, DR, and UR domains means that some authors inform more than one domain. However, this limitation is balanced by the fact that these domains are influenced by different drivers. For example, CR is influenced by psychology and disaster management, while its operationalization is being driven on the ground by the community service development sectors. Conversely, DR is strongly influenced by policy and logistics around preventing, preparing for, responding to, and recovering from the increased frequency and intensity of extreme weather events while its practice or implementation is being driven by government and nongovernment agencies responsible for provision of emergency and supporting services to disaster affected communities (Gotham and Campanella 2011). Similarly, the different framings of resilience in the UR domain reflect diverse theoretical and disciplinary traditions, including urban ecosystems, disaster risk management, and global-local environmental and socioeconomic impacts/shocks. Hence, there is sufficient diversity of framings within these domains to counter the problem of an overlapping focus.

Step 4 comprised a process to construct the typology of resilience interpretations, beginning with the classification of resilience definitions. Existing classifications are confined to identification of broad definitional characteristics (Manyena 2006, Cretney 2014), or lists of illustrative definitions (Zhou et al. 2010, Aldunce et al. 2014, Lei et al. 2014), while there are limited examples of more refined resilience classifications (Brand and Jax 2007, Bhamra et al. 2011). Our objectives of demonstrating convergence and evolution among the selected resilience domains and contributing to conceptual clarity necessitated a more conceptually sophisticated classification system. Hence, the conceptual typology was selected as an appropriate methodology.

The main merit of conceptual typologies is in reducing complexity by bringing order to an eclectic mix of cases through sorting them into a few relatively homogeneous types distinguished by a few important dimensions (Bailey 1994). Although typologies have some weaknesses, they are still regarded as providing "a sound foundation for both theorizing and empirical research" (Bailey 1994:33, see also Doty and Glick 1994, Lagendijk 2003, Moore and Koontz 2003, Fiss 2011). These features confirmed the appropriateness of our choice of methodology. 
The typology process involved, first, mapping the occurrence of conceptual elements against the classification of resilience definitions and, second, clustering subcategories of definitions based on their constituent elements to construct the typology of ideal resilience types. Each cluster represents an ideal resilience type.

\section{RESULTS}

Results from our analysis of the main features of resilience interpretations, associated conceptual traditions, and treatments of CSI are described here to demonstrate their maturation and convergence in understanding resilience. Resilience conceptual elements are outlined and definitional differences within domains are identified as the basis for typology construction.

\section{Comparison of resilience definitions and conceptual traditions}

The earliest definitions of ER describe the capacity of a complex ecological system to persist or to absorb change while preserving its structure and function (Holling 1973). "Ecological resilience," which Holling (1996) and others (for example, Gunderson 2000) distinguished from "engineering resilience," addresses concerns related to the unpredictability of change and the uncertainty of the environment, replacing the single equilibrium and single stable state positions of mainstream ecology with the idea of multiple stable states, often far from equilibrium.

The concept of SER, which evolved from Hollings' work on ER, has become accepted as a useful heuristic for understanding, responding to and managing change in linked human-ecological systems (SES). It is widely acknowledged that the concept provides a crucial middle ground between social and environmental sciences, and that it has been important in bringing together scholars from these disciplines with a shared interest in environmental change leading to important research and insights (for example, Davidson 2010 and Kirchhoff et al. 2010). Capacities for adaptability, transformability, self-organization, and learning have become fundamental SER concepts (Folke et al. 2010).

From these advances in ecological theory, understanding has developed that natural and human systems are strongly coupled, behave in complex nonlinear ways, and are continuously changing and evolving. SER theorists found complex adaptive systems (CAS) theory highly compatible with their thinking (Lansing 2003, Levin 2003) and this theory has contributed greatly to understanding the dynamics of change in these linked socialecological systems, particularly the dynamics of system stability, the operation of structures and functions across spatial and temporal scales, and the ability of drivers on one level to influence change at other levels (Gunderson and Holling 2002, Berkes et al. 2003, Sengupta 2006). Encapsulated as concepts of alternative stable states, the adaptive cycle and the panarchy, respectively (Gunderson and Holling 2002), these understandings have become essential foundations of SER thinking.

In the UR domain, resilience is often discussed in the context of crises and a return to a pre-existing stability domain. However, there is evidence of challenges to this engineering resilience understanding and associated attempts to integrate it into a human-dominated, built environment context (Alberti and Marzluff 2004, Ernstson et al. 2010). The equilibrium view of resilience is apparent in urban planning's ongoing focus on the structure of cities, including the City Beautiful metaphor that resulted in sterile office blocks and dangerous public housing (Pickett et al. 2004). More recently, nonequilibrium views have emerged in response to arguments that equilibrium-based approaches are ill-equipped to explain the geographical diversity, variety, and unevenness of the resilience of places (Pendall et al. 2010, Pike et al. 2010), while nonequilibrium resilience is said to better account for the ability of urban systems to adapt and adjust to changing influences (Pickett et al. 2004). Thus, an integrated and holistic, dynamic and evolutionary SER interpretation is proving more useful to urban planning (Davoudi 2012, Davoudi et al. 2013).

Within the DR literature, preoccupation with responses to crises often precipitated by natural disasters leads to an emphasis on resistance capability, catastrophe absorption, and timely recovery from loss (Boin et al. 2010, de Bruijne et al. 2010, Zhou et al. 2010). Less reactive definitions focus on disaster prevention, vulnerability reduction, timely adaptation to a changed reality, and regeneration capacity (Paton and Johnston 2006, Maguire and Hagan 2007, Lavell et al. 2012, Heazle et al. 2013), reflecting the view that $\mathrm{DR}$ is a more positive and proactive focus for disaster management than disaster vulnerability (Cutter et al. 2008).

Until recently, DR and UR domains tended to an equilibrium view of resilience influenced by a risk and hazard management paradigm and backed by notions of stability and resistance to change (Adger et al. 2005, Berkes 2007). However, recent disaster experiences, such as the catastrophe inflicted on New Orleans by Hurricane Katrina, have exposed the limitations of this approach (Boin and McConnell 2007) so that DR is moving toward a more integrated paradigm (Boin and McConnell 2007, Park et al. 2011, Cox 2012, Djalante et al. 2012, 2013), that has shifted from prevention/control and mitigation/vulnerability to adaptation/ transformation (O'Brien 2012, O'Brien et al. 2012, Lei et al. 2014). Hence, emphasis increasingly centers on the ability of complex systems to deal with hazards (Berkes 2007) and community capacities to respond well to crises through building and maintaining social capital and social resilience (Norris et al. 2008, Cutter et al. 2010, Brown and Westaway 2011, Cox 2012, Cohen et al. 2013).

Much of the discussion around CR too occurs in relation to risks and crises so that resilience is often adopted in its engineering sense of ability to bounce back and recover to a pre-existing regime thus emphasizing risk minimization and recovery support (Brown 2014). Broader definitions incorporate social parameters so that $\mathrm{CR}$ is interpreted as a capacity of the social system to work toward a common objective (Magis 2010, Berkes and Ross 2013). This interpretation favors community self-reliance and capacity-building to reduce vulnerability to stressful events (Twigg 2009).

CR draws from two disciplinary areas, psychological resilience and disaster management (Berkes and Ross 2013). Psychological resilience is largely concerned with how people cope with adversity, psychological risk factors, and individual sensitivities to trauma (Sonn and Fisher 1998, Juliano and Yunes 2014), although, more recently, psychologists have become interested in how structures and processes within communities and cultures affect how people deal with change (Juliano and Yunes 2014). Contemporary CR scholarship overlaps with disaster 
management research, and specifically focuses at the community scale (Berkes and Ross 2013), considering the collective resources (capitals) that enable individuals to respond to change, and the collective processes (e.g., governance arrangements) that support them to do so (Cutter et al. 2008). CR considers both system characteristics that support change and the processes through which agency can be created and enacted (Wilson 2012a, Brown 2014) so as to retain a community's core structures and processes (Magis 2010).

\section{Treatment of cross-scale interactions}

We found limited evidence of CSI interpreted as a key conceptual element of resilience definitions in its own right in any of the five domains. References are restricted to external influences that drive adaptive responses within the focal system (for example, Folke et al. 2010) and limited to the SER domain. And yet, the broader literature suggests there is considerable differentiation between the domains on this aspect and recognition of CSI as a critical resilience factor is increasing. Unsurprisingly, both ER and SER domains have engaged with CSI as an intrinsic property of CAS, along with nonlinearity, self-organization, feedbacks, and emergence (Cumming and Norberg 2008, Levin 1998, Levin et al. 2013). CSI are acknowledged as an essential driver of ecological resilience, dependent on the distributions of functional groups across scales, and functional and response diversity at multiple scales (Drever et al. 2006, Peterson et al. 1998). Similarly, the importance of cross-scale linkages to SES resilience is wellrecognized (Berkes 2007) and is most clearly expressed in the concept of the panarchy (Gunderson and Holling 2002). Thus, cross-scale subsidies and resource inputs can either be a source of, or impediment to, resilience (Abel et al. 2006); and solutions to complex problems may require explication of the interconnections of multiple causes, consequences, and crossscale actors of the problem (FitzGibbon and Mensah 2012), comanagement and multilevel governance approaches (Olsson et al. 2007), or conscious boundary management (Cash et al. 2006); while the establishment of institutional linkages between SES is an effective means of building resilience to nonlocalized hazards (Gotham and Campanella 2011).

Conversely, attention to cross-scale interaction is a recent phenomenon in the remaining domains. Various authors, including Gotham and Campanella (2011) and Pendall et al. (2010), argue for consideration of cross-scale interactions in urban policies, such as policy-setting at the local level, e.g., water supply where there is potential to cause impacts beyond the defined geographical boundary. Cross-scale linkages must also be considered from temporal perspectives in enabling the system to deal with future shocks (Pendall et al. 2010), address temporal trade-offs, and avoid "lock-in" policies that reduce opportunities for learning and changing (Chelleri et al. 2015, Pike et al. 2010). Similarly in the DR domain, consideration of resilience in hazardprone mountain SES has extended from localized hazards to the need to develop cross-scale institutional linkages between SES facing similar hazards (Gardner and Dekens 2007), while difficulties of building DR at different spatial and temporal scales, e.g., drought resilience in agricultural areas, to reduce disaster impacts are also acknowledged (Zhou et al. 2010).

Moreover, within the CR literature, Brown (2014) argues for consideration of cross-scale issues, given social science critiques of inattention to power and agency in social applications of resilience concepts. Wilson $(2012 b, 2013)$ and Singer et al. (2015) maintain that exogenous drivers acting across institutional scales can function to either strengthen or weaken some capitals important for community resilience, and that this is significant for the practical application of resilience concepts, given that these drivers can affect policy corridors, and therefore transformational pathways. Cross scale interactions, evidenced through the likes of climate adaptation planning, also demonstrably affect community economies, cultural practices, and social networks meaning that those with particular capitals become more or less vulnerable than others (Crane 2010, Singer et al. 2015), and therefore that some groups are better able to take advantage of change than others. Many community resilience assessments (e.g., Daze et al. 2009, Bours et al. 2013, Tyler et al. 2014) now explicitly consider crossscale drivers of community resilience, particularly around governance and planning, in a perceived attempt to ensure the concept is practically relevant.

\section{Evolution and convergence trends}

The analysis of resilience interpretations across the domains identified three definitional levels for each resilience domain. The diversity and maturational paths followed by resilience interpretations are captured in the classification of interpretations and their subcategories derived from the literature reviews and summarized in Table 1. The definitional levels were determined by noting the occurrence of conceptual elements within definitions. These elements are described in Table 2. Although there were distinct differences in definitions that enabled the isolation of the three levels within each domain, generally each succeeding level was observed to build on the previous one by including additional conceptual elements, thus demonstrating maturation or evolution of the concept, as illustrated in Figure 1. For example, early definitions of SER were confined to persistence to or absorption of disturbance, and retaining system identity, while later definitions added self-organization and adaptability, and more recently transformability.

Fig. 1. Key resilience conceptual elements identified in resilience definition subcategories grouped by resilience domains

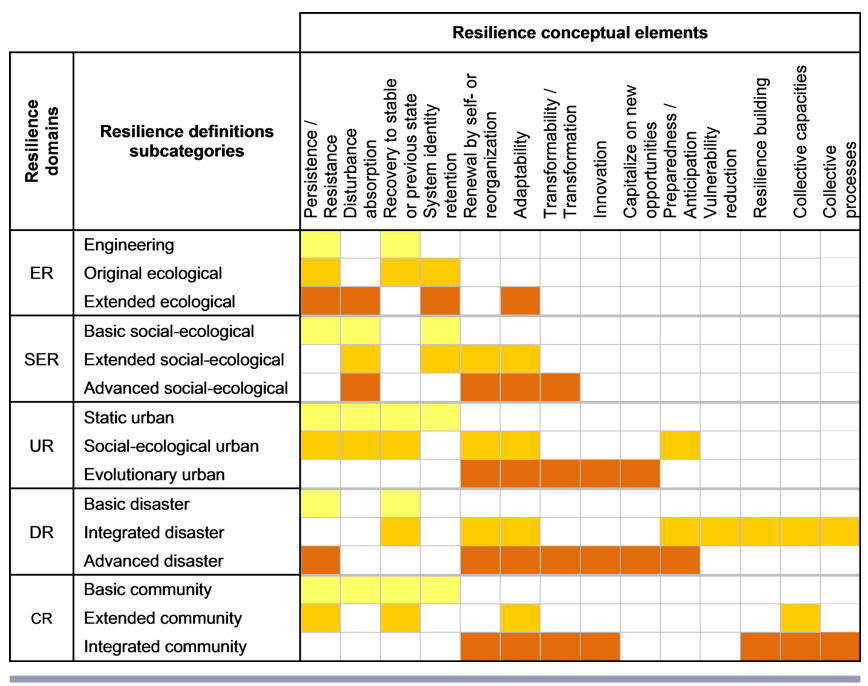


Table 1. Classification of resilience definitions illustrating interpretational evolution in ecological, social-ecological, urban, disaster, and community resilience domains.

\begin{tabular}{lcc}
\hline \hline $\begin{array}{l}\text { Domains } \\
\begin{array}{l}\text { Resilience definition } \\
\text { subcategories }\end{array}\end{array}$ & Description & Cxamples of definitions \\
\hline
\end{tabular}

ER

Engineering

Original ecological

Extended ecological

SER

Basic social-ecological The ability of social-ecological systems to absorb disturbance or persist against extrinsic or endogenous change, both recurrent and unexpected, and thus remain within the same system space or stability domain by maintaining the same function, structure, identity, and feedbacks

Extended socialecological The tendency of a SES subject to change to remain within the critical thresholds of a stability domain through its capacity to renew itself by reorganizing its subsystems, by learning and adaptation, and by building these capacities.

Advanced socialecological

UR

Static urban

Social-ecological urban adapt/adjust to internal and external change processes, whether from shocks or accumulating hazards, by reorganizing its subsystems so as to minimize disruption to them. change its structure and functions to shift the system to an alternative regime or onto an alternative development trajectory when the system is trapped in an untenable regime or a decision is made to shift to a different regime.

The ability of an urban system or city to withstand a wide array of shocks and stresses so that its subsystems (physical, social, economic, and natural) return to their previous (normal) form or condition.
Holling (1996), Holling and Gunderson (2002)

Rate at which a system returns to a single steady or cyclic state following perturbation (Holling 1986).

Holling (1973), Holling (1996), “... a measure of the persistence of systems and of their Gunderson (2000), Beisner et al. ability to absorb change and disturbance and still maintain (2003), Drever et al. (2006), Brand and Jax (2007) the same relationships between populations or state variables" (Holling 1973:14).

Peterson et al. (1998), Gunderson and Holling (2002), the system changes its structure by changing the variables and Peterson (2002), Walker et al. processes that control behavior" (Gunderson and Holling (2006), Brand (2009), Mumby et 2002:4). al. (2014)

"... the capacity of a system to experience shocks while retaining essentially the same function, structure, feedbacks, and therefore identity" (Walker et al. 2006:2).

Walker and Salt (2006)

"Resilience is the capacity of a system to absorb disturbance; to undergo change and still retain essentially the same function, structure and feedbacks ... without crossing a threshold to a different system regime" (Walker et al. 2006:32).

Berkes and Jolly (2001), Carpenter et al. (2001), Walker recurrent disturbances such as hurricanes or floods so as to et al. (2002), Alcorn et al. (2003), retain essential structures, processes, and feedbacks; ... the Tompkins and Adger (2004), degree to which a complex adaptive system is capable of selfAdger et al. (2005), Folke (2006), organization (versus lack of organization or organization Asah (2008), Folke et al. (2010), forced by external factors); and the degree to which the Plummer (2010), Cumming et al. system can build capacity for learning and adaptation" (2013) (Adger et al. 2005:1036).

Walker et al. (2004), Folke et al. "Resilience is the tendency of a SES subject to change to (2010), IPCC (2014), Rockström remain within a stability domain, continually changing and et al. (2014)

Alberti and Marzluff (2004), Colding (2007), Ernstson et al. (2010), Leichenko (2011) Schewenius et al. (2014)

Pickett et al. (2004), Newman et al. (2009), Surjan et al. (2011) Jabareen (2013), Beichler et al. (2014) adapting yet remaining within critical thresholds. Adaptability is a part of resilience. Adaptability is the capacity of a SES to adjust its responses to changing external drivers and internal processes and thereby allow for development within the current stability domain, along the current trajectory. Transformability is the capacity to create new stability domains for development, a new stability landscape, and cross thresholds into a new development trajectory" (Folke et al. 2010:20).

"The capacity of social, economic, and environmental systems to cope with a hazardous event or trend or disturbance, responding or reorganizing in ways that maintain their essential function, identity, and structure, while also maintaining the capacity for adaptation, learning, and transformation" (IPCC 2014:5).

"... the ability of a city or urban system to withstand a wide array of shocks and stresses" (Leichenko 2011:165). "... the capacity of an ecosystem to absorb disturbance and reorganize while undergoing change so as to retain essentially the same function, structure, identity and feedbacks" (Colding 2007:46).

"... a resilient city is defined by the overall abilities of its governance, physical, economic and social systems and entities exposed to hazards to learn, be ready in advance, plan for uncertainties, resist, absorb, accommodate to and recover from the effects of a hazard in a timely and efficient manner, including through the preservation and restoration of its essential basic structures and functions" (Jabareen 2013:227).

"... resilience should not be confined to the ability of a system to return to its stable state after disruption, but to also adapt and adjust to changing internal or external processes" (Cartalis 2014:264). 


\begin{tabular}{|c|c|c|c|}
\hline Evolutionary urban & $\begin{array}{l}\text { The ability of an urban system or city to } \\
\text { respond to the new requirements imposed } \\
\text { by internal and external shocks or change } \\
\text { processes by learning, adapting, } \\
\text { reorganizing, and transforming its } \\
\text { subsystems to take advantage of new } \\
\text { opportunities }\end{array}$ & $\begin{array}{l}\text { Godschalk (2003), Brown et al. } \\
\text { (2012), Chelleri (2012), Davoudi } \\
\text { et al. (2013), Cartalis (2014), } \\
\text { Polèse (2015) }\end{array}$ & $\begin{array}{l}\text { Resilience is not just a response to external shocks but also } \\
\text { the capacity to reorganize, take advantage of new situations, } \\
\text { and respond to new requirements (Cartalis 2014). } \\
\text { Evolutionary resilience implies that social-ecological systems } \\
\text { can change radically over time with or without an external } \\
\text { disturbance (Davoudi 2012). }\end{array}$ \\
\hline Basic disaster & $\begin{array}{l}\text { The tendency to address resilience to risks } \\
\text { and hazards reactively through resistance, } \\
\text { relief, and recovery approaches }\end{array}$ & $\begin{array}{l}\text { de Bruijne et al. (2010), Janssen } \\
\text { et al. (2006) }\end{array}$ & $\begin{array}{l}\text { “... the measure of a system's, or part of a system's, capacity } \\
\text { to absorb and recover from the occurrence of a hazardous } \\
\text { event” (Timmerman 1981:21). }\end{array}$ \\
\hline Integrated disaster & $\begin{array}{l}\text { The capacity of a SES to proactively } \\
\text { prevent, anticipate, adapt to, and recover } \\
\text { from hazards and risks, both anticipated } \\
\text { and unexpected, through multi- and } \\
\text { interdisciplinary participatory approaches } \\
\text { to managing uncertainties, building } \\
\text { community resilience, and reducing } \\
\text { community vulnerability }\end{array}$ & $\begin{array}{l}\text { Klein et al. (2003), Manyena } \\
\text { (2006), Maguire and Hagan } \\
\text { (2007), IPCC (2012), Djalante et } \\
\text { al. (2013), Heazle et al. (2013), } \\
\text { Van Niekerk (2013), Lei et al. } \\
\text { (2014), Howes et al. (2015) }\end{array}$ & $\begin{array}{l}\text { "... the intrinsic capacity of a system, community or society } \\
\text { predisposed to a shock or stress to adapt and survive by } \\
\text { changing its non-essential attributes and rebuilding itself" } \\
\text { (Manyena 2006:446). } \\
\text { "Adaptive and integrated disaster resilience ... is defined as } \\
\text { the ability of nations and communities to build resilience in } \\
\text { an integrated manner and strengthen mechanisms to build } \\
\text { system adaptiveness" (Dialante et al. 2013:2105). }\end{array}$ \\
\hline Advanced disaster & $\begin{array}{l}\text { A measure of how well people and societies } \\
\text { deal with disruptive change through } \\
\text { capacities for anticipation, adaptation, and } \\
\text { improvization, and their ability to } \\
\text { capitalize on the new opportunities offered } \\
\text { or to innovate }\end{array}$ & $\begin{array}{l}\text { Paton and Johnston (2006), Boin } \\
\text { and McConnell (2007), Boin et } \\
\text { al. (2010), Zhou et al. (2010) }\end{array}$ & $\begin{array}{l}\text { "... resilience is a measure of how well people and societies } \\
\text { can adapt to a changed reality and capitalize on the new } \\
\text { possibilities offered ... an element of learning and growth } \\
\text { should be implicit in the conceptualization, as should the } \\
\text { notion of disaster as catalyst for development" (Paton and } \\
\text { Johnston 2006:8). }\end{array}$ \\
\hline Basic community & $\begin{array}{l}\text { The ability to withstand and recover or } \\
\text { bounce back from external shocks or } \\
\text { disasters }\end{array}$ & $\begin{array}{l}\text { Black and Hughes (2001), } \\
\text { Ainuddin and Routray (2012), } \\
\text { Chandra et al. (2013) }\end{array}$ & $\begin{array}{l}\text { "... the ability of the community to bounce back, respond to, } \\
\text { recover from and absorb the impacts and cope with } \\
\text { earthquake" (Ainuddin and Routray 2012:911). } \\
\text { "A resilient community is one that is able to respond } \\
\text { effectively and bounce back in the face of adverse } \\
\text { circumstances, whether these be economic, environmental or } \\
\text { social" (Black and Hughes 2001:16) }\end{array}$ \\
\hline Extended community & $\begin{array}{l}\text { The collective capacities (either inherent or } \\
\text { adaptive) that communities have to } \\
\text { withstand, adapt to, and recover from } \\
\text { shocks to their social infrastructure }\end{array}$ & $\begin{array}{l}\text { Adger (2000), Ahmed et al. } \\
\text { (2004), Norris et al. (2008), } \\
\text { Magis (2010), Sherrieb et al. } \\
\text { (2010), Plough et al. (2013) }\end{array}$ & $\begin{array}{l}\text { "... a process linking a network of adaptive capacities } \\
\text { (resources with dynamic attributes) [economic development, } \\
\text { information and communication, community competencies, } \\
\text { and social capital] to adaptation after a disturbance or } \\
\text { adversity" (Norris et al. 2008:127). } \\
\text { "... community resilience includes those features of a } \\
\text { community, which, in general, promote the safety of its } \\
\text { residents; which serve to protect residents against injury and } \\
\text { violence risks; and which allow residents to recover after } \\
\text { exposure to general adversity and injury risks" (Ahmed et al. } \\
\text { 2004:387). }\end{array}$ \\
\hline Integrated community & $\begin{array}{l}\text { The processes that community members } \\
\text { collectively use to develop and engage } \\
\text { collective capacities (adaptation and self- } \\
\text { organization) and resources (physical, } \\
\text { economic, and social) in order to thrive in } \\
\text { communities subject to change, uncertainty, } \\
\text { unpredictability, and surprise }\end{array}$ & $\begin{array}{l}\text { Norris et al. (2008), Twigg } \\
\text { (2009), Magis (2010), Berkes and } \\
\text { Ross (2013), Skerratt (2013), } \\
\text { Wilson (2013), Ross and Berkes } \\
\text { (2014) }\end{array}$ & $\begin{array}{l}\text { “... the existence, development and engagement of } \\
\text { community resources by community members to thrive in an } \\
\text { environment characterized by change, uncertainty, } \\
\text { unpredictability and surprise" (Magis 2010:401). } \\
\text { An integrated approach to community resilience considers } \\
\text { the interaction between adaptive capacity and agency on one } \\
\text { hand, and community characteristics (such as leadership, } \\
\text { values and beliefs, knowledge, skills and learning, networks, } \\
\text { engaged governance, community infrastructure, diverse and } \\
\text { innovative economy) that influence agency and self- } \\
\text { organization on the other. It also considers resilience-building } \\
\text { processes in practice (Berkes and Ross 2013). }\end{array}$ \\
\hline
\end{tabular}

Interestingly, not only is evolution of resilience definitions evident but so is their theoretical convergence particularly around the social-ecological interpretation that is providing the basis for definitions used by other domains, that is, the system can absorb disturbance, reorganize and adapt, yet retain the same function, structure, identity, and feedbacks (Colding 2007, Schewenius et al. 2014). Convergence, particularly around themes of self- or reorganization, adaptability, and transformation, is evident for the most mature interpretations of SER, UR, and CR, but less so for the advanced DR interpretation, where innovation rather than transformation is a key element.

Although increasing adoption of the resilience approach is apparent in those disciplines addressing the impacts of global, mostly environmental, change, we note that this is not universal with uptake among social sciences disciplines being more limited. Indeed, the idea that the ecological concept of resilience can be applied to social systems on the assumption that human communities function and behave similarly to ecological systems is highly contested (Adger 2000, Cote and Nightingale 2012). One proposition that could have significant ramifications for resilience's practical effectiveness is that it is criticized for being a one-sided paradigm, termed ecological organicism by Kirchhoff et al. (2010), with distinct but unacknowledged cultural presumptions about the relationship between individuality and society, captured by the term individual holism (Kirchhoff et al. 2010). The problem is that other competing notions of individualism that might support consideration of alternative approaches to ecosystem management are excluded (Kirchhoff et al. 2010). Hence, Olsson et al. (2015) contend that the 
Table 2. Resilience conceptual elements and their descriptions.

\begin{tabular}{|c|c|}
\hline Resilience conceptual elements & Description \\
\hline Persistence / Resistance & $\begin{array}{l}\text { Complementary aspects referring to the amount of external pressure that it takes to disturb a system. Some } \\
\text { systems persist because they are resistant to external disturbance. }\end{array}$ \\
\hline Absorption of change or disturbance & The amount of change or disturbance that a system can absorb without changing to a different state. \\
\hline Recovery to stable or previous state & The assumption that systems will bounce back to their previous stable state after disturbance \\
\hline System identity retained & Refers to retention of system function, structure and feedbacks despite experiencing disturbance \\
\hline Renewal via self- / reorganization & $\begin{array}{l}\text { The capacity for renewal in complex adaptive systems experiencing disturbance through internal self- } \\
\text { directed structural change }\end{array}$ \\
\hline Adaptability & $\begin{array}{l}\text { The capacity of complex adaptive systems to learn, adapt and build resilience in response to changing } \\
\text { internal and external drivers and maintain the current development trajectory }\end{array}$ \\
\hline Transformability / transformation & $\begin{array}{l}\text { The ability to transition intentionally to a new system with different structure, functions, feedbacks and } \\
\text { outputs. Intentional transformation generally costs less than unintended transformation. }\end{array}$ \\
\hline Innovation & $\begin{array}{l}\text { An important response mechanism in times of system crisis, renewal and when transformational change is } \\
\text { needed; integral to the reorganization phase of the adaptive cycle }\end{array}$ \\
\hline Capitalize on new opportunities & $\begin{array}{l}\text { A capacity to make the most of new development opportunities afforded by new situations and to take } \\
\text { advantage of windows of opportunity }\end{array}$ \\
\hline Preparedness / Anticipation & A capacity to anticipate, plan for and be prepared for uncertainties \\
\hline Vulnerability reduction & $\begin{array}{l}\text { Improving capacity to withstand and cope with hazards, reducing the impact of hazards, and reducing } \\
\text { general risk causes }\end{array}$ \\
\hline Resilience building & $\begin{array}{l}\text { Fostering development of those elements that will enable social-ecological systems to absorb and/or adapt to } \\
\text { unforeseen change and deal with uncertainties - learning to live with change, maintaining diversity (natural, } \\
\text { cultural, social, economic, institutional) to increase options, combining different types of knowledge for } \\
\text { learning, and providing opportunities for self-organization }\end{array}$ \\
\hline Collective capacities & $\begin{array}{l}\text { Capacities or resources (economic, social, cultural, spiritual, and political resources) available to } \\
\text { communities for a collective response to change and adversity }\end{array}$ \\
\hline Collective processes & $\begin{array}{l}\text { Processes that communities use to translate capacities into actions that strengthen their potential to respond } \\
\text { to change, such as governance processes broadly, and active engagement in planning, community decision- } \\
\text { making and initiatives more specifically }\end{array}$ \\
\hline
\end{tabular}

unificatory claims made for resilience theory may be an example of reductive "disciplinary imperialism," where a single theory outcompetes other superior explanations, in this case, of persistent complex social problems, such as global environmental change.

Concerns have also been expressed about the failure to recognize resilience as socially contingent ("resilience for whom?"), the preoccupation with external drivers (disturbances), and the underplaying of internal social system processes (Brown 2014), while the inability of resilience theory to account for agency as well as structural variables is also disputed (Davidson 2010). Political ecologists criticize the failure to account for politics and power relations, and the effects of power asymmetries, particularly, "who decides the most desirable system state?" (Nadasdy 2007). MacKinnon and Derickson (2013) argue that the inherent conservatism of the concept through the focus on system persistence plays to neoliberal ideas of community responsibility whereby responsibility is devolved to communities to adapt to the logic and effects of global capitalism (Welsh 2014). As well, the resilience framework has been criticized for being too deterministic to account for the multiple incongruities in feedback processes operating in the complex global capitalist system thus challenging the presumption of a direct positive relationship between complexity and resilience (Davidson 2010).

\section{Resilience conceptual elements and the Resilience Typology} Although the core resilience components of persistence, absorption, recovery, identity retention, self-organization, adaptability, and transformation are common to all definitions to greater or lesser degrees, additional elements of a social nature, such as, preparedness, vulnerability reduction, resilience building, capitalization, and collective capacities and processes, are embedded only in UR, DR, and CR domain definitions. This adds an extra layer of complexity to definitions used within these domains. The difference is that while ecological and engineering systems are managed by people, their resilience is inherent in their own structure and function, whereas the SER, UR, DR, and CR domains make people an integral part of the system.

From the clustering of similar subcategories of definitions and their constituent elements, three ideal resilience types (Fig. 2) were identified:

- Type 1 comprising engineering, original ecological, essential social-ecological, static urban, basic disaster, and basic community resilience definitions;

- Type 2 including extended ecological, extended socialecological, social-ecological urban, integrated disaster, and extended community resilience definitions;

- Type 3 consisting of advanced social-ecological, evolutionary urban, advanced disaster, and integrated community resilience definitions.

Analysis of Figure 2 shows that the ideal types of resilience interpretation are defined by their inclusion of particular conceptual elements. Although there is overlap of some elements, each type is differentiated by elements that are specific only to that interpretation type. Type 1, or "basic resilience," has four core elements comprising persistence or resistance, absorption of disturbance, recovery or bouncing back to a previous stable state, and retention of system identity. Type 2, or "adaptive resilience," 
may include some or all Type 1 elements, but self-organization and adaptability typify this ideal. Type 3 , or "transformative resilience," incorporates some elements from Type 1 and both unique Type 2 elements, but transformability is the element that clearly distinguishes this type. The seven conceptual elements included in the three ideal types constitute core elements while the remaining elements are discipline-specific elements restricted to UR, DR, and CR definitions. The elements in this latter group are not essential to the ideal types but may be essential to specific resilience interpretations and applications.

Fig. 2. Typology of ideal resilience interpretations showing core and discipline-specific resilience conceptual elements comprising each type

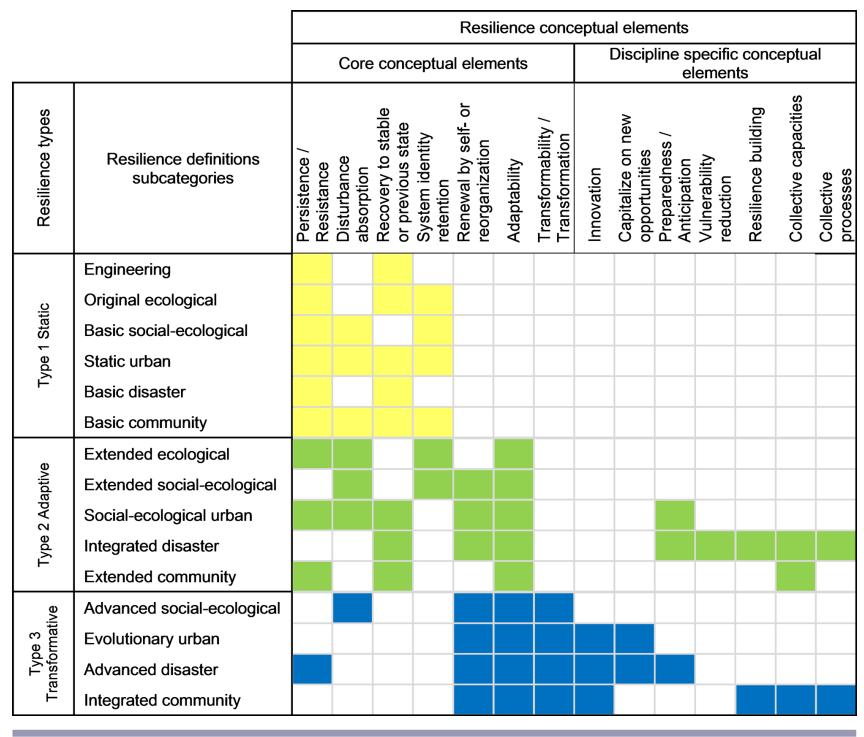

\section{DISCUSSION}

An emergent resilience paradigm?

Although definitions of resilience have been described as multiple, sometimes contradictory, and somewhat fuzzy, identification of underlying theoretical traditions and the mapping of consistently occurring conceptual elements within definitions has enabled us to demonstrate their evolution and convergence across the five selected domains. Moreover, the nascent trend toward engagement with the significance of interactions with scales beyond the focal scale in UR, DR, and CR domains confirms this observation.

The analysis also suggests, at least in the literature if not in practice, a convergence toward the most mature SER interpretation with additional social elements that reflect the particular emphases of UR, DR, and CR domains. Furthermore, although the selected resilience domains are informed by diverse theoretical traditions, because of the growing convergence around the SER interpretation, the dominant conceptual influence is currently coming from CAS and complexity theory. This trend has implications for resilience application in practical and policy contexts.

Following Kuhn (1970), we could argue from our observations that the current diversity of, and competition among, resilience interpretations constitutes a preparadigmatic movement while the perceived convergence of interpretations and underlying theoretical bases is a possible indicator of an emerging resilience paradigm. Such a paradigm would entail appearance of a consensus around the fundamentals of resilience - its constituent concepts, framing theories, language, and metaphysical assumptions - thus permitting agreement on the problems to be solved and the development of an "exemplary" resilience science. Only then will "intelligent management" of the problems associated with uncertainty and complexity be possible (Ravetz 2006:279).

\section{Interpreting the typology}

In this analysis, we utilized the potential of typologies to clarify the conceptual elements that are core to resilience thinking. Conceptual clarity was achieved by (i) systematically ordering diverse resilience definitions according to their constituent conceptual elements and (ii) distinguishing the fundamental conceptual elements essential to understanding resilience as a conceptual framework from those that are associated with particular resilience interpretations but are not essential to the base concept.

By using the typology to clarify the core conceptual elements, we were able to distinguish which elements are closely associated. We also found that closeness of association among elements is controlled by the amount and nature of change influencing systems. Thus, the level of system disturbance is the key dependent variable differentiating the ideal types of resilience.

Moreover, identification of this variable enabled us to make sense of the relationships among elements comprising particular resilience types. For example, the four elements comprising Type 1 basic resilience are related in reducing disturbance and maintaining system status quo, while the elements of Type 2 adaptive resilience are related to adapting to change but maintaining structure and function. Conversely, the defining Type 3 transformative resilience element, transformability, involves a transition, either purposeful or unintended, from the status quo and replacement of adaptation as the lead change response.

Each ideal type is composed of a unique combination of conceptual elements that will characterize a specific resilience response to a given degree of system disturbance. The amount and nature of change varies for each resilience type and will influence the approach taken in operationalizing resilience (Serrao-Neumann et al. 2016). Thus, for Type 1 resilience contexts, where vulnerability to change impacts is relatively low, policy and practice for change can be limited to absorbing or resisting disturbance, and maintaining the current system state and identity. For example, in a system where the climate is stable with a manageable level of impacts including from extreme events, a Type 1 resilience interpretation would be appropriate. To illustrate by way of a concrete example, a Type 1 response to a disaster event such as a wildfire or flood might be the promises made by politicians, or demands made by residents, that the damaged properties be replaced by similar structures in the same location. In more vulnerable and dynamic Type 2 contexts, such as in a system experiencing a changing climate with an elevated level of climate extremes, Figure 2 suggests that policy and practice considerations focused on capacities for renewal through self- or reorganization and adaptability would be sufficient. At this level of disturbance, disaster responses could encompass 
improved building structures that are adapted to withstand increased flood or wildfire risk, undertaking preventative measures, and establishing collaborative community organizations to build community resilience. In highly vulnerable and dynamic Type 3 contexts, however, such as for a system facing a regime shift as a result of heightened impacts from extreme climate events and possibly other change drivers, operationalizing resilience must follow a transformative path. In this case, disaster responses could involve relocation of whole communities away from vulnerable flood or wildfire prone sites altogether.

The implications of these three interpretation types are significant for practice. First, this analysis implies that policy makers and managers should have a comprehensive understanding of the change environment with which they are dealing. Second, system dynamics and unpredictability mean that the appropriate interpretation type for resilience practice may be required to change, as the dynamics and stability of systems change. Understanding the shifts in systems and the responses is challenging, given that each type includes different conceptual elements. For example, CR Type 1 could be assessed through persistence of collective identity, e.g., culture; for Type 2, this identity would persist despite adaptability, e.g., changes in agriculture cropping patterns because of climate impacts. For a CR Type 3 interpretation, we would also need to consider indicators of collective capacities and processes that enable a community to adapt in self-determined ways, such as the strength of local governance processes or education levels that would enable more transformative pathways to be identified, e.g., shifts in livelihood strategies from agrarian smallholding to tourism and market-based agriculture. Thus, there are limitations to the application and practice of resilience building when narrow and singular interpretation types are applied.

\section{CONCLUSIONS}

In developing the resilience typology, the set of interconnected problems we were seeking to address was primarily the following:

- confusion surrounding the multiple interpretations of the resilience concept, stemming from a lack of consensus and fuzziness around its meaning;

- resulting difficulties in applying resilience that have impeded ongoing improvement of its operationalization;

- challenges in measuring progress in building or maintaining resilience; and

- the likelihood that the resilience concept will become nothing more than a rhetorical device unless these issues are resolved.

Through our analysis we showed that although there are some conceptual elements that appear in most interpretations, other elements occur sporadically and are domain specific (Fig. 1). We argued that it is this variation that makes it difficult to operationalize the concept of resilience in terms of an agreed definition, setting goals, and measuring progress.

The typology contributes to conceptual clarity by: (i) reducing the confusion resulting from multiple resilience interpretations and therefore helping to order systematic research into better understanding resilience across diverse domains; and (ii) integrating diverse resilience interpretations to identify ideal resilience types and clarify core and domain-specific conceptual elements. Albeit that our analysis of these elements is a snap-shot in time, showing which elements are converging and which are not is helpful to conceptual clarity.

Given that resilience is the objective of many management actions, our classification and typology afford guidance on the conceptual elements that could inform resilience applications in different domains, while providing broad conceptual categories as the basis for developing consistent foundational indicators to measure changes in resilience. From a practical perspective, better consistency and clarity in applying resilience, better targeted resilience-building measures/activities, and cross-domain lessons (e.g., SER could learn to incorporate agency by reference to CR scholarship on community capacities and processes) could be expected. Although it is known that domains do not acknowledge the use of resilience in other domains (Alexander 2013), increased recognition of these varied interpretations should be encouraged because individual domains have much to learn from each other. Indeed, this paper represents an example of inter- and transdisciplinary efforts to address these shortcomings and a timely intervention to strengthen the practical and explanatory authority of resilience.

In considering the future of resilience as a useful problem-solving paradigm under conditions of complexity and uncertainty, one option might be to use the common conceptual elements as a starting point to build the consensus of a mature resilience paradigm that allows agreement on fundamentals and the key resilience problems requiring solutions, while providing consistency and clarity in its application. Our demonstration of an emergent resilience paradigm may indicate that competition among disciplines could possibly be replaced by consensus on resilience fundamentals in the near future.

Finally, if SER emerges as the dominant resilience interpretation, conceptual clarity and effective practice require that care be taken to avoid resilience becoming a one-sided paradigm by further interrogating its cultural presumptions and leavening with insights from alternative resilience interpretations and social science traditions. This could involve investigating the links between cultural and ecological diversity and the resulting implications for resilience-building, transformation, and innovation and renewal. Further investigation may also be needed into the issue of power and agency and SER, including, for example, whether SER and CR are more beneficially held in tension or whether they can build from one another. Another area that deserves attention involves the tools used in DR, UR, and CR domains for assessing and/or building resilience, vulnerability, or adaptation, and whether these are fundamentally different; whether these domains could learn from each other, and, if so, how?; and why collective processes, capacities, and resilience building are not being better considered in DR and UR domains. Last, further development of emergent understanding around cross-scale effects within the nonecological domains is also warranted, particularly focusing on CSI as they apply to the core components of the emerging resilience paradigm: adaptation, transformation, innovation, and renewal; how does scale affect these elements?; and what does that mean for the way we assess and build resilience?. Additionally, if we are to advance a more critical understanding of resilience's multiscale dimensions, CSI 
could be better recognized as a necessary condition for system resilience and become a core element of resilience definitions across all domains.

Responses to this article can be read online at: http://www.ecologyandsociety.org/issues/responses. $\mathrm{php} / 8450$

\section{Acknowledgments:}

The authors wish to express their gratitude to the reviewers for their insightful comments and suggestions and to gratefully acknowledge the support of the University of the Sunshine Coast Research Futures Project funded by the Australian Government's Collaborative Research Network Program for the collaborative writing program under which this paper was researched and authored.

\section{LITERATURE CITED}

Abel, N., D. H. M. Cumming, and J. M. Anderies. 2006. Collapse and reorganization in social-ecological systems: questions, some ideas, and policy implications. Ecology and Society 11(1):17. [online] URL: http://www.ecologyandsociety.org/vol11/iss1/ art17/

Adger, W. N. 2000. Social and ecological resilience: are they related? Progress in Human Geography 24(3):347-364. http://dx. doi.org/10.1191/030913200701540465

Adger, W. N., T. P. Hughes, C. Folke, S. R. Carpenter, and J. Rockström. 2005. Social-ecological resilience to coastal disasters. Science 309:1036-1039. http://dx.doi.org/10.1126/science.1112122

Ahmed, R., M. Seedat, A. van Niekerk, and S. Bulbulia. 2004. Discerning community resilience in disadvantaged communities in the context of violence and injury prevention. South African Journal of Psychology 34:386-408. http://dx.doi.org/10.1177/008124630403400304

Ainuddin, S., and J. K. Routray. 2012. Earthquake hazards and community resilience in Baluchistan. Natural Hazards 63 (2):909-937. http://dx.doi.org/10.1007/s11069-012-0201-x

Alberti, M., and J. M. Marzluff. 2004. Ecological resilience in urban ecosystems: linking urban patterns to human and ecological functions. Urban Ecosystems 7(3):241-265. http://dx. doi.org/10.1023/b:ueco.0000044038.90173.c6

Alcorn, J. B., J. Bamba, S. Masiun, I. Natalia, and A. Royo. 2003. Keeping ecological resilience afloat in cross-scale turbulence: an indigenous social movement navigates change in Indonesia. Pages 299-327 in F. Berkes, J. Colding, and C. Folke, editors. Navigating social-ecological systems: building resilience for complexity and change. Cambridge University Press, Cambridge, UK. http://dx. doi.org/10.1017/cbo9780511541957.018

Aldunce, P., R. Beilin, J. Handmer, and M. Howden. 2014. Framing disaster resilience: the implications of the diverse conceptualisations of "bouncing back." Disaster Prevention and Management 23(3):252-270. http://dx.doi.org/10.1108/dpm-07-2013-0130
Alexander, D. E. 2013. Resilience and disaster risk reduction: an etymological journey. Natural Hazards and Earth Systems Science 13(11):2707-2716. http://dx.doi.org/10.5194/nhess-13-2707-2013

Asah, S. T. 2008. Empirical social-ecological system analysis: from theoretical framework to latent variable structural equation model. Environmental Management 42(6):1077-1090. http://dx. doi.org/10.1007/s00267-008-9172-9

Bailey, K. D. 1994. Typologies and taxanomies: an introduction to classification techniques. Sage, Thousand Oaks, California, USA.

Beichler, S. A., S. Hasibovic, B. J. Davidse, and S. Deppisch. 2014. The role played by social-ecological resilience as a method of integration in interdisciplinary research. Ecology and Society 19 (3):4. http://dx.doi.org/10.5751/es-06583-190304

Beisner, B. E., D. T. Haydon, and K. Cuddington. 2003. Alternative stable states in ecology. Frontiers in Ecology and the Environment 1(7):376-382. http://dx.doi.org/10.1890/1540-9295 (2003)001[0376:assie]2.0.co;2

Benson, M. H., and R. K. Craig. 2014. The end of sustainability. Society \& Natural Resources 27(7):777-782. http://dx.doi. org/10.1080/08941920.2014.901467

Berkes, F. 2007. Understanding uncertainty and reducing vulnerability: lessons from resilience thinking. Natural Hazards 41(2):283-295. http://dx.doi.org/10.1007/s11069-006-9036-7

Berkes, F., J. Colding, and C. Folke. 2003. Introduction. Pages 1-30 in F. Berkes, J. Colding and C. Folke, editors. Navigating social-ecological systems: building resilience for complexity and change. Cambridge University Press, Cambridge, UK. http://dx. doi.org/10.1017/cbo9780511541957.003

Berkes, F., and D. Jolly. 2001. Adapting to climate change: socialecological resilience in a Canadian western Arctic community. Conservation Ecology 5(2):18. [online] URL: http://www. ecologyandsociety.org/vol5/iss2/art18/

Berkes, F., and H. Ross. 2013. Community resilience: toward an integrated approach. Society \& Natural Resources 26(1):5-20. http://dx.doi.org/10.1080/08941920.2012.736605

Bhamra, R., S. Dani, and K. Burnard. 2011. Resilience: the concept, a literature review and future directions. International Journal of Production Research 49(18):5375-5393. http://dx.doi. org/10.1080/00207543.2011.563826

Black, A., and P. Hughes. 2001. The identification and analysis of indicators of community strength and outcomes. Department of Family and Community Services, Government of Australia, Canberra, Australia.

Bohensky, E. L. 2008. Discovering resilient pathways for South African water management: two frameworks for a vision. Ecology and Society 13(1):19. [online] URL: http://www.ecologyandsociety. org/vol13/iss1/art19/

Boin, A., L. K. Comfort, and C. C. Demchak. 2010. The rise of resilience. Pages 1-12 in L. K. Comfort, A. Boin and C. C. Demchak, editors. Designing resilience: preparing for extreme events. University of Pittsburgh Press, Pittsburgh, Pennsylvania, USA. 
Boin, A., and A. McConnell. 2007. Preparing for critical infrastructure breakdowns: the limits of crisis management and the need for resilience. Journal of Contingencies and Crisis Management 15(1):50-59. http://dx.doi.org/10.1111/

j.1468-5973.2007.00504.X

Bours, D., C. McGinn, and P. Pringle. 2013. Monitoring \& evaluation for climate change adaptation: a synthesis of tools, frameworks and approaches. SEA Change CoP, Phnom Penh, Cambodia and UKCIP, Oxford, UK.

Brand, F. 2009. Critical natural capital revisited: ecological resilience and sustainable development. Ecological Economics 68 (3):605-612. http://dx.doi.org/10.1016/j.ecolecon.2008.09.013

Brand, F. S., and K. Jax. 2007. Focusing the meaning(s) of resilience: resilience as a descriptive concept and a boundary object. Ecology and Society 12(1):23.

Brown, A., A. Dayal, and C. Rumbaitis Del Rio. 2012. From practice to theory: emerging lessons from Asia for building urban climate change resilience. Environment and Urbanization 24 (2):531-556. http://dx.doi.org/10.1177/0956247812456490

Brown, K. 2014. Global environmental change I: a social turn for resilience? Progress in Human Geography 38(1):107-117. http://dx. doi.org/10.1177/0309132513498837

Brown, K., and E. Westaway. 2011. Agency, capacity, and resilience to environmental change: lessons from human development, well-being, and disasters. Annual Review of Environment and Resources 36(1):321-342. http://dx.doi. org/10.1146/annurev-environ-052610-092905

Carpenter, S., B. Walker, J. M. Anderies, and N. Abel. 2001. From metaphor to measurement: resilience of what to what? Ecosystems 4(8):765-781. http://dx.doi.org/10.1007/s10021-001-0045-9

Cartalis, C. 2014. Toward resilient cities - a review of definitions, challenges and prospects. Advances in Building Energy Research 8(2):259-266. http://dx.doi.org/10.1080/17512549.2014.890533

Cash, D. W., W. N. Adger, F. Berkes, P. Garden, L. Lebel, P. Olsson, L. Pritchard, and O. Young. 2006. Scale and cross-scale dynamics: governance and information in a multilevel world. Ecology and Society 11(2):8. [online] URL: http://www.ecologyandsociety. org/vol11/iss $2 / \operatorname{art} 8 /$

Chandra, A., M. Williams, A. Plough, A. Stayton, K. B. Wells, M. Horta, and J. Tang. 2013. Getting actionable about community resilience: the Los Angeles County Community Disaster Resilience Project. American Journal of Public Health 103(7):1181-1189. http://dx.doi.org/10.2105/ajph.2013.301270

Chelleri, L. 2012. From the "resilient city" to urban resilience. A review essay on understanding and integrating the resilience perspective for urban systems. Documents d'anàlisi geogràfica 58 (2):287-306.

Chelleri, L., J. J. Waters, M. Olazabal, and G. Minucci. 2015. Resilience trade-offs: addressing multiple scales and temporal aspects of urban resilience. Environment and Urbanization 27 (1):181-198. http://dx.doi.org/10.1177/0956247814550780

Cohen, I. S., Ú. O. Spring, G. D. Padilla, J. C. Paredes, M. A. Inzunza Ibarra, R. L. López, and J. V. Díaz. 2013. Forced migration, climate change, mitigation and adaptive policies in Mexico: some functional relationships. International Migration 51(4):53-72. http://dx.doi.org/10.1111/j.1468-2435.2012.00743.x

Colding, J. 2007. 'Ecological land-use complementation' for building resilience in urban ecosystems. Landscape and Urban Planning 81(1-2):46-55. http://dx.doi.org/10.1016/j. landurbplan.2006.10.016

Cote, M., and A. J. Nightingale. 2012. Resilience thinking meets social theory: situating social change in socio-ecological systems (SES) research. Progress in Human Geography 36(4):475-489. http://dx.doi.org/10.1177/0309132511425708

Cox Jr., L. A. 2012. Community resilience and decision theory challenges for catastrophic events. Risk Analysis 32 (11):1919-1934. http://dx.doi.org/10.1111/j.1539-6924.2012.01881. $\underline{\mathrm{X}}$

Crane, T. A. 2010. Of models and meanings: cultural resilience in social-ecological systems. Ecology and Society 15(4):19. [online] URL: http://www.ecologyandsociety.org/vol15/iss4/art19/

Cretney, R. 2014. Resilience for whom? Emerging critical geographies of socio-ecological resilience. Geography Compass 8 (9):627-640. http://dx.doi.org/10.1111/gec3.12154

Cumming, G. S., and J. Norberg. 2008. Scale and complex systems. Pages 246-276 in J. Norberg and G. S. Cumming, editors. Complexity theory for a sustainable future. Columbia University Press, New York, New York, USA.

Cumming, G. S., P. Olsson, F. S. Chapin III, and C. S. Holling. 2013. Resilience, experimentation, and scale mismatches in socialecological landscapes. Landscape Ecology 28(6):1139-1150. http://dx.doi.org/10.1007/s10980-012-9725-4

Cutter, S. L., L. Barnes, M. Berry, C. Burton, E. Evans, E. Tate, and J. Webb. 2008. A place-based model for understanding community resilience to natural disasters. Global Environmental Change 18(4):598-606. http://dx.doi.org/10.1016/j.gloenvcha.2008.07.013

Cutter, S. L., C. G. Burton, and C. T. Emrich. 2010. Disaster resilience indicators for benchmarking baseline conditions. Journal of Homeland Security and Emergency Management 7 (1):23. http://dx.doi.org/10.2202/1547-7355.1732

Davidson, D. J. 2010. The applicability of the concept of resilience to social systems: some sources of optimism and nagging doubts. Society \& Natural Resources 23(12):1135-1149. http://dx.doi. org/10.1080/08941921003652940

Davoudi, S. 2012. Resilience: a bridging concept or a dead end? Planning Theory \& Practice 13(2):299-307.

Davoudi, S., E. Brooks, and A. Mehmood. 2013. Evolutionary resilience and strategies for climate adaptation. Planning Practice \& Research 28(3):307-322. http://dx.doi.org/10.1080/02697459.2$\underline{013.787695}$

Daze, A., K. Ambrose, and C. Ehrhart. 2009. Climate vulnerability and capacity analysis handbook. Care International, Atlanta, Georgia, USA.

de Bruijne, M., A. Boin, and M. van Eeten. 2010. Resilience: exploring the concept and its meanings. Pages 13-32 in L. K. Comfort, A. Boin and C. C. Demchak, editors. Designing 
resilience: preparing for extreme events. University of Pittsburgh Press, Pittsburgh, Pennsylvania, USA.

Deppisch, S., and S. Hasibovic. 2013. Social-ecological resilience thinking as a bridging concept in transdisciplinary research on climate-change adaptation. Natural Hazards 67(1):117-127. http://dx.doi.org/10.1007/s11069-011-9821-9

Djalante, R., C. Holley, F. Thomalla, and M. Carnegie. 2013. Pathways for adaptive and integrated disaster resilience. Natural Hazards 69(3):2105-2135. http://dx.doi.org/10.1007/s11069-013-0797-5

Djalante, R., F. Thomalla, M. S. Sinapoy, and M. Carnegie. 2012. Building resilience to natural hazards in Indonesia: progress and challenges in implementing the Hyogo Framework for Action. Natural Hazards 62(3):779-803. http://dx.doi.org/10.1007/ s11069-012-0106-8

Doty, D. H., and W. H. Glick. 1994. Typologies as a unique form of theory building: toward improved understanding and modeling. Academy of Management Review 19(2):230-251.

Drever, C. R., G. Peterson, C. Messier, Y. Bergeron, and M. Flannigan. 2006. Can forest management based on natural disturbances maintain ecological resilience? Canadian Journal of Forest Research 36(9):2285-2299. http://dx.doi.org/10.1139/ $\underline{\mathrm{x} 06-132}$

Ernstson, H., S. E. van der Leeuw, C. L. Redman, D. J. Meffert, G. Davis, C. Alfsen, and T. Elmqvist. 2010. Urban transitions: on urban resilience and human-dominated ecosystems. Ambio 39 (8):531-545. http://dx.doi.org/10.1007/s13280-010-0081-9

Fiss, P. C. 2011. Building better causal theories: a fuzzy set approach to typologies in organization research. Academy of Management Journal 54(2):393-420. http://dx.doi.org/10.5465/ amj.2011.60263120

FitzGibbon, J., and K. O. Mensah. 2012. Climate change as a wicked problem: an evaluation of the institutional context for rural water management in Ghana. Sage Open 2(2):1-14. http:// dx.doi.org/10.1177/2158244012448487

Folke, C. 2006. Resilience: the emergence of a perspective for social-ecological systems analyses. Global Environmental Change 16(3):253-267. http://dx.doi.org/10.1016/j.gloenvcha.2006.04.002

Folke, C., S. R. Carpenter, B. H. Walker, M. Scheffer, T. Chapin, and J. Rockström. 2010. Resilience thinking: integrating resilience, adaptability and transformability. Ecology and Society 15(4):20. [online] URL: http://www.ecologyandsociety.org/vol15/ $\underline{\text { iss } 4 / \operatorname{art} 20 /}$

Folke, C., F. S. Chapin III, and P. Olsson. 2009. Transformations in ecosystem stewardship. Pages 103-125 in F. S. Chapin III, G. Kofinas, and C. Folke, editors. Principles of ecosystem stewardship: resilience-based natural resource management in a changing world. Springer, New York, New York, USA. http://dx. doi.org/10.1007/978-0-387-73033-2 5

Gardner, J. S., and J. Dekens. 2007. Mountain hazards and the resilience of social-ecological systems: lessons learned in India and Canada. Natural Hazards 41(2):317-336. http://dx.doi. org/10.1007/s11069-006-9038-5
Godschalk, D. 2003. Urban hazard mitigation: creating resilient cities. Natural Hazards Review 4(3):136-143. http://dx.doi. org/10.1061/(asce)1527-6988(2003)4:3(136)

Gotham, K. F., and R. Campanella. 2011. Coupled vulnerability and resilience: the dynamics of cross-scale interactions in postKatrina New Orleans. Ecology and Society 16(3):12. http://dx.doi. org/10.5751/es-04292-160312

Gunderson, L. H. 2000. Ecological resilience - in theory and application. Annual Review of Ecology and Systematics 31:425-439. http://dx.doi.org/10.1146/annurev.ecolsys.31.1.425

Gunderson, L. H., and C. S. Holling, editors. 2002. Panarchy: understanding transformations in human and natural systems. Island Press, Washington, D.C., USA.

Heazle, M., P. Tangney, P. Burton, M. Howes, D. Grant-Smith, K. Reis, and K. Bosomworth. 2013. Mainstreaming climate change adaptation: an incremental approach to disaster risk management in Australia. Environmental Science \& Policy 33:162-170. http://dx.doi.org/10.1016/j.envsci.2013.05.009

Holling, C. S. 1973. Resilience and stability of ecological systems. Annual Review of Ecological Systems 4:1-23. http://dx.doi. org/10.1146/annurev.es.04.110173.000245

Holling, C. S. 1986. The resilience of terrestrial ecosystems; local surprise and global change. Pages 292-317 in W. C. Clark and R. E. Munn, editors. Sustainable development of the biosphere. Cambridge University Press, Cambridge, U.K.

Holling, C. S. 1996. Engineering resilience versus ecological resilience. Pages 31-44 in P. Schulze, editor. Engineering within ecological constraints. National Academy, Washington, D.C., USA.

Holling, C. S., and L. H. Gunderson. 2002. Resilience and adaptive cycles. Pages 25-62 in L. H. Gunderson and C. S. Holling, editors. Panarchy: understanding transformations in human and natural systems. Island Press, Washington, D.C., USA.

Howes, M., P. Tangney, K. Reis, D. Grant-Smith, M. Heazle, K. Bosomworth, and P. Burton. 2015. Towards networked governance: improving interagency communication and collaboration for disaster risk management and climate change adaptation in Australia. Journal of Environmental Planning and Management 58(5):757-776. http://dx.doi.org/10.1080/09640568.2014 .891974

Intergovernmental Panel on Climate Change (IPCC). 2012. Managing the risks of extreme events and disasters to advance climate change adaptation. A Special Report of Working Groups I and II Of the Intergovernmental Panel on Climate Change. C. B. Field, V. Barros, T. F. Stocker, D. Qin, D. J. Dokken, K. L. Ebi, M. D. Mastrandrea, K. J. Mach, G.-K. Plattner, S. K. Allen, M. Tignor, and G. F. Midgley, editors. Cambridge University Press, Cambridge, UK.

Intergovernmental Panel on Climate Change (IPCC). 2014. Summary for policymakers. Pages 1-32 in C. B. Field, V. R. Barros, D. J. Dokken, K. J. Mach, M. D. Mastrandrea, T. E. Bilir, M. Chatterjee, K. L. Ebi, Y. O. Estrada, R. C. Genova, B. Girma, E. S. Kissel, A. N. Levy, S. MacCracken, P. R. Mastrandrea and L. 
L. White, editors. Climate Change 2014: impacts, adaptation, and vulnerability. Part A: global and sectoral aspects. Contribution of Working Group II to the Fifth Assessment Report of the Intergovernmental Panel on Climate Change. Cambridge University Press, Cambridge, UK.

Jabareen, Y. 2013. Planning the resilient city: concepts and strategies for coping with climate change and environmental risk. Cities 31:220-229. http://dx.doi.org/10.1016/j.cities.2012.05.004

Janssen, M. A., M. L. Schoon, W. Ke, and K. Börner. 2006. Scholarly networks on resilience, vulnerability and adaptation within the human dimensions of global environmental change. Global Environmental Change 16:240-252. http://dx.doi. org/10.1016/j.gloenvcha.2006.04.001

Juliano, M. C. C., and M. A. M. Yunes. 2014. Reflections on the social support network as a mechanism for the protection and promotion of resilience Ambiente \& Sociedade 17(3):135-154. http://dx.doi.org/10.1590/S1414-753X2014000300009

Kirchhoff, T., F. S. Brand, D. Hoheisel, and V. Grimm. 2010. The one-sidedness and cultural bias of the resilience approach. Gaia 19(1):25-32.

Klein, R. J. T., R. J. Nicholls, and F. Thomalla. 2003. Resilience to natural hazards: How useful is this concept? Global Environmental Change Part B: Environmental Hazards 5(1):35-45. http://dx.doi.org/10.1016/j.hazards.2004.02.001

Kuhn, T. 1970. The structure of scientific revolutions. University of Chicago Press, Chicago, Illinois, USA.

Lagendijk, A. 2003. Towards conceptual quality in regional studies: the need for subtle critique - a response to Markusen. Regional Studies 37(6-7):719-727. http://dx.doi.org/10.1080/003$\underline{4340032000108804}$

Lansing, J. S. 2003. Complex adaptive systems. Annual Review of Anthropology 32:183-204. http://dx.doi.org/10.1146/annurev. anthro.32.061002.093440

Lavell, A., J. C. Gaillard, B. Wisner, W. Saunders, and D. van Niekerk. 2012. National planning and disaster. Pages 617-628 in B. Wisner, J. C. Gaillard, and I. Kelman, editors. The Routledge handbook of hazards and disaster risk reduction. Routledge, Abingdon, UK. http://dx.doi.org/10.4324/9780203844236.ch51

Lei, Y., J. Wang, Y. Yue, H. Zhou, and W. Yin. 2014. Rethinking the relationships of vulnerability, resilience, and adaptation from a disaster risk perspective. Natural Hazards 70(1):609-627. http:// dx.doi.org/10.1007/s11069-013-0831-7

Leichenko, R. 2011. Climate change and urban resilience. Current Opinion in Environmental Sustainability 3(3):164-168. http://dx. doi.org/10.1016/j.cosust.2010.12.014

Levin, S., T. Xepapadeas, A.-S. Crépin, J. Norberg, A. de Zeeuw, C. Folke, T. Hughes, K. Arrow, S. Barrett, G. Daily, P. Ehrlich, N. Kautsky, K.-G. Mäler, S. Polasky, M. Troell, J. R. Vincent, and B. Walker. 2013. Social-ecological systems as complex adaptive systems: modeling and policy implications. Environment and Development Economics 18(02):111-132. http://dx.doi.org/10.1017/ $\underline{\mathrm{s} 1355770 \times 12000460}$
Levin, S. A. 1998. Ecosystems and the biosphere as complex adaptive systems. Ecosystems 1(5):431-436. http://dx.doi. org/10.1007/s100219900037

Levin, S. A. 2003. Complex adaptive systems: exploring the known, the unknown and the unknowable. Bulletin (New Series) of the American Mathematical Society 40(1):3-19. http://dx.doi. org/10.1090/s0273-0979-02-00965-5

MacKinnon, D., and K. D. Derickson. 2013. From resilience to resourcefulness: a critique of resilience policy and activism. Progress in Human Geography 37(2):253-270. http://dx.doi. org/10.1177/0309132512454775

Magis, K. 2010. Community resilience: an indicator of social sustainability. Society \& Natural Resources 23(5):401-416. http:// dx.doi.org/10.1080/08941920903305674

Maguire, B., and P. Hagan. 2007. Disasters and communities: understanding social resilience. Australian Journal of Emergency Management 22(2):16-20.

Manyena, S. B. 2006. The concept of resilience revisited. Disasters 30(4):434-450. http://dx.doi.org/10.1111/j.0361-3666.2006.00331. $\underline{\mathrm{x}}$

Markusen, A. 1999. Fuzzy concepts, scanty evidence, policy distance: the case for rigour and policy relevance in critical regional studies. Regional Studies 33(9):869-884. http://dx.doi. org/10.1080/00343409950075506

Moore, E. A., and T. M. Koontz. 2003. Research note: a typology of collaborative watershed groups: citizen-based, agency-based, and mixed partnerships. Society \& Natural Resources 16 (5):451-460. http://dx.doi.org/10.1080/08941920309182

Mumby, P. J., I. Chollett, Y.-M. Bozec, and N. H. Wolff. 2014. Ecological resilience, robustness and vulnerability: how do these concepts benefit ecosystem management? Current Opinion in Environmental Sustainability 7:22-27. http://dx.doi.org/10.1016/j. cosust.2013.11.021

Nadasdy, P. 2007. Adaptive co-management and the gospel of resilience. Pages 208-227 in D. Armitage, F. Berkes, and N. Doubleday, editors. Adaptive co-management: collaboration, learning and multi-level governance. University of British Columbia Press, Vancouver, British Columbia, Canada.

Newman, P., T. Beatley, and H. M. Boyer. 2009. Resilient cities: responding to peak oil and climate change. Island Press, Washington, D.C., USA

Norris, F. H., S. P. Stevens, B. Pfefferbaum, K. F. Wyche, and R. L. Pfefferbaum. 2008. Community resilience as a metaphor, theory, set of capacities, and strategy for disaster readiness. American Journal of Community Psychology 41(1-2):127-150. http://dx.doi.org/10.1007/s10464-007-9156-6

O'Brien, K. 2012. Global environmental change II: from adaptation to deliberate transformation. Progress in Human Geography 36(5):667-676. http://dx.doi.org/10.1177/0309132511425767

O'Brien, K., M. Pelling, A. Patwardhan, S. Hallegatte, A. Maskrey, T. Oki, U. Oswald-Spring, T. Wilbanks, and P. Z. Yanda. 2012. Toward a sustainable and resilient future. Pages 437-486 in C. B. Field, V. Barros, T. F. Stocker, D. Qin, D. J. Dokken, K. L. 
Ebi, M. D. Mastrandrea, K. J. Mach, G.-K. Plattner, S. K. Allen, M. Tignor, and P. M. Midgley, editors. Managing the risks of extreme events and disasters to advance climate change adaptation. A Special Report of Working Groups I and II of the Intergovernmental Panel on Climate Change. Cambridge University Press, Cambridge, UK. http://dx.doi.org/10.1017/ $\underline{\text { cbo9781139177245.011 }}$

Olsson, L., A. Jerneck, H. Thoren, J. Persson, and D. O'Byrne. 2015. Why resilience is unappealing to social science: theoretical and empirical investigations of the scientific use of resilience. Science Advances 1(4):e1400217. http://dx.doi.org/10.1126/ sciadv. 1400217

Olsson, P., C. Folke, and F. Berkes. 2004. Adaptive comanagement for building resilience in social-ecological systems. Environmental Management 34(1):75-90. http://dx.doi.org/10.1007/s00267-003-0101-7

Olsson, P., C. Folke, V. Galaz, T. Hahn, and L. Schultz. 2007. Enhancing the fit through adaptive co-management: creating and maintaining bridging functions for matching scales in the Kristianstads Vattenrike Biosphere Reserve, Sweden. Ecology and Society 12(1):28. [online] URL: http://www.ecologyandsociety. org/vol12/iss1/art28/

Olsson, P., C. Folke, and T. P. Hughes. 2008. Navigating the transition to ecosystem-based management of the Great Barrier Reef, Australia. Proceedings of the National Academy of Sciences 105(28):9489-9494. http://dx.doi.org/10.1073/pnas.0706905105

Park, J., T. P. Seager, and P. S. C. Rao. 2011. Lessons in risk- versus resilience-based design and management. Integrated Environmental Assessment and Management 7(3):396-399. http://dx.doi. org/10.1002/ieam.228

Paton, D., and D. Johnston. 2006. Disaster resilience: an integrated approach. Charles C. Thomas, Springfield, Illinois, USA.

Pendall, R., K. A. Foster, and M. Cowell. 2010. Resilience and regions: building understanding of the metaphor. Cambridge Journal of Regions, Economy and Society 3(1):71-84. http://dx.doi. org/10.1093/cjres/rsp028

Peterson, G. D. 2002. Estimating resilience across landscapes. Conservation Ecology 6(1):17. [online] URL: http://www. ecologyandsociety.org/vol6/iss 1/art17/

Peterson, G., C. R. Allen, and C. S. Holling. 1998. Ecological resilience, biodiversity, and scale. Ecosystems 1(1):6-18. http://dx. doi.org/10.1007/s100219900002

Pickett, S. T. A., M. L. Cadenasso, and J. M. Grove. 2004. Resilient cities: meaning, models, and metaphor for integrating the ecological, socio-economic, and planning realms. Landscape and Urban Planning 69(4):369-384. http://dx.doi.org/10.1016/j. landurbplan.2003.10.035

Pike, A., S. Dawley, and J. Tomaney. 2010. Resilience, adaptation and adaptability. Cambridge Journal of Regions, Economy and Society 3(1):59-70. http://dx.doi.org/10.1093/cjres/rsq001

Plough, A., J. E. Fielding, A. Chandra, M. Williams, D. Eisenman, K. B. Wells, G. Y. Law, S. Fogleman, and A. Magaña. 2013. Building community disaster resilience: perspectives from a large urban county department of public health. American Journal of
Public Health 103(7):1190-1197. http://dx.doi.org/10.2105/ ajph.2013.301268

Plummer, R. 2010. Social-ecological resilience and environmental education: synopsis, application, implications. Environmental Education Research 16(5-6):493-509. http://dx.doi. org/10.1080/13504622.2010.505423

Polèse, M. 2015. The resilient city: on the determinants of successful urban economies. Pages 145-161 in R. Paddison and T. Hutton, editors. Cities and economic change: restructuring and dislocation in the global metropolis. Sage, London, UK.

Ravetz, J. R. 2006. Post-normal science and the complexity of transitions towards sustainability. Ecological Complexity 3 (4):275-284. http://dx.doi.org/10.1016/j.ecocom.2007.02.001

Rockström, J., M. Falkenmark, C. Folke, M. Lannerstad, J. Barron, E. Enfors, L. Gordon, J. Heinke, H. Hoff, and C. PahlWostl. 2014. Water resilience for human prosperity Cambridge University Press, Cambridge, UK. http://dx.doi.org/10.1017/ CBO9781139162463

Ross, H., and F. Berkes. 2014. Research approaches for understanding, enhancing, and monitoring community resilience. Society \& Natural Resources 27(8):787-804. http://dx.doi. org/10.1080/08941920.2014.905668

Schewenius, M., T. McPhearson, and T. Elmqvist. 2014. Opportunities for increasing resilience and sustainability of urban social-ecological systems: insights from the URBES and the cities and biodiversity outlook projects. Ambio 43(4):434-444. http:// dx.doi.org/10.1007/s13280-014-0505-Z

Sengupta, N. 2006. Fragmented landholding, productivity, and resilience management. Environment and Development Economics 11(04):507-532. http://dx.doi.org/10.1017/s1355770x0600307x

Serrao-Neumann, S., J. L. Davidson, C. L. Baldwin, A. Dedekorkut-Howes, J. C. Ellison, N. J. Holbrook, M. Howes, C. Jacobson, and E. A. Morgan. 2016. Marine governance to avoid tipping points: Can we adapt the adaptability envelope? Marine Policy 65:56-67. http://dx.doi.org/10.1016/j.marpol.2015.12.007

Sherrieb, K., F. H. Norris, and S. Galea. 2010. Measuring capacities for community resilience. Social Indicators Research 99 (2):227-247. http://dx.doi.org/10.1007/s11205-010-9576-9

Singer, J., H. Hoang, and C. Ochiai. 2015. Post-displacement community resilience: considering the contribution of indigenous skills and cultural capital among ethnic minority Vietnamese. Asia Pacific Viewpoint 56(2):208-222. http://dx.doi.org/10.1111/ apv. 12057

Skerratt, S. 2013. Enhancing the analysis of rural community resilience: evidence from community land ownership. Journal of Rural Studies 31:36-46. http://dx.doi.org/10.1016/j.jrurstud.2013.02.003

Sonn, C. C., and A. T. Fisher. 1998. Sense of community: community resilient responses to oppression and change. Journal of Community Psychology 26(5):457-472. http://dx.doi. org/10.1002/(SICI)1520-6629(199809)26:5<457::AID-JCOP5>3.0. CO;2-O

Stead, D. 2013. Urban planning, water management and climate change strategies: adaptation, mitigation and resilience narratives 
in the Netherlands. International Journal of Sustainable Development \& World Ecology 21(1):15-27. http://dx.doi. org/10.1080/13504509.2013.824928

Strunz, S. 2012. Is conceptual vagueness an asset? Arguments from philosophy of science applied to the concept of resilience. Ecological Economics 76:112-118. http://dx.doi.org/10.1016/j. ecolecon.2012.02.012

Surjan, A., A. Sharma, and R. Shaw. 2011. Understanding urban resilience. Pages 17-45 in R. Shaw and A. Sharma, editors. Climate and disaster resilience in cities. Emerald Books, Bingley, UK. http://dx.doi.org/10.1108/S2040-7262(2011)0000006008

Timmerman, P. 1981. Vulnerability, resilience and the collapse of society: a review of models and possible climatic applications. Institute for Environmental Studies, University of Toronto, Toronto, Ontario, Canada.

Tompkins, E. L., and W. N. Adger. 2004. Does adaptive management of natural resources enhance resilience to climate change? Ecology and Society 9(2):10. [online] URL: http://www. ecologyandsociety.org/vol9/iss2/art10/

Twigg, J. 2009. Characteristics of a disaster-resilient community: a guidance note (version 2). Department for International Development's Disaster Risk Reduction Inter-agency Coordination Group, London, UK.

Tyler, S., E. Nugraha, H. K. Nguyen, N. Van Nguyen, A. D. Sari, P. Thinpanga, T. T. Tran, S. S. Verma, D. Swanson, and L. Bizikova. 2014. Developing indicators of urban climate resilience. ISET Climate Resilience Working Paper \#2. Institute for Social and Environmental Transition, Boulder, Colorado, USA.

Van Niekerk, W. 2013. Translating disaster resilience into spatial planning practice in South Africa: challenges and champions. Jàmbá: Journal of Disaster Risk Studies 5(1):1-6. http://dx.doi. org/10.4102/jamba.v5i1.53

Walker, B., S. R. Carpenter, J. Anderies, N. Abel, G. S. Cumming, M. Janssen, L. Lebel, J. Norberg, G. D. Peterson, and R. Pritchard. 2002. Resilience management in social-ecological systems: a working hypothesis for a participatory approach. Ecology and Society 6(1):14. [online] URL: http://www. ecologyandsociety.org/vol6/iss1/art14/

Walker, B. H., L. H. Gunderson, A. P. Kinzig, C. Folke, S. R. Carpenter, and L. Schultz. 2006. A handful of heuristics and some propositions for understanding resilience in social-ecological systems. Ecology and Society 11(1):13. [online] URL: http://www. ecologyandsociety.org/vol11/iss1/art13/

Walker, B., C. S. Holling, S. R. Carpenter, and A. Kinzig. 2004. Resilience, adaptability and transformability in social-ecological systems. Ecology and Society 9(2):5. [online] URL: http://www. ecologyandsociety.org/vo19/iss2/art5/

Walker, B., and D. Salt. 2006. Resilience thinking: sustaining ecosystems and people in a changing world. Island Press, Washington, D.C., USA.

Welsh, M. 2014. Resilience and responsibility: governing uncertainty in a complex world. Geographical Journal 180 (1):15-26. http://dx.doi.org/10.1111/geoj.12012
Wilson, G. A. 2012a. Community resilience and environmental transitions. Routledge, Abingdon, UK.

Wilson, G. A. 2012b. Community resilience, globalization, and transitional pathways of decision-making. Geoforum 43 (6):1218-1231. http://dx.doi.org/10.1016/j.geoforum.2012.03.008

Wilson, G. A. 2013. Community resilience, policy corridors and the policy challenge. Land Use Policy 31:298-310. http://dx.doi. org/10.1016/j.landusepol.2012.07.011

Zhou, H., J. Wang, J. Wan, and H. Jia. 2010. Resilience to natural hazards: a geographic perspective. Natural Hazards 53(1):21-41. http://dx.doi.org/10.1007/s11069-009-9407-y 